\title{
The Juridical Position of Greek Minorities in Albania
}

Marenglen Cobo

Phd Europian University of Tirana

\section{Abstract}

Greek minority played an important role in the life and formation of the Albanian State. This minority has been concentrated mainly in the south of the country, more specifically in the border areas between Albania and Greece. The role of this minority has been important not only in the cultural development but also in the affirmation of the Albanian State. The Greek minority has been known legally as a national minority in 1921 when Albania was accepted in the League of Nations as a sovereign state with full rights. The admission to this international organisation was conditional upon the signing of a document in which Albania committed to recognise and guarantee full rights to minorities living in its territory. This document entitled "declaration on the protection of minorities in Albania" would force the Albanian State to submit detailed reports to the League of Nations about the situation of the minorities in the country. All minorities within the country lost their status after the end of the Second World War, during the Communist regime of Enver Hoxha. After the collapse of communism and the advent of democracy, minority rights were affirmed not only in the Albanian jurisdiction but also by several international agreements, such as the Convention of the Council of Europe for Protection of National Minorities. The actual judicial system in Albania guarantees national minorities equal rights with the Albanian population and, simultaneously, allows the preservation of their national identity.

Keywords: Greek minority, the League of Nations, protection of minorities, convention, communist regime.

\section{Introduction}

\subsection{Recognition of national minorities in Albania and the declaration on the protection of national minorities.}

With regard to the population composition, Albania is a homogenous state, inside of which live, although in a small percentage, some minorities of different nationality from the majority. Such national minorities are mainly settled in border areas of the Albanian territory. In the northern part of the country live Montenegrin minorities, in the southeastern part of the country live Macedonian minorities, whereas in the southern part of such territory live Greek minorities, with the latter making up the most powerful community in terms of numbers. The Greek minority can be mostly found in the region of Gjirokaster, Korce and Himara.

National minorities were legally recognized following the adherence of Albania, on 17 December 1921, as a member state to the League of Nations. As a condition to such adherence, the Albanian government had to sign a document, where by Albania should engage in the recognition and respect of the rights of the national minorities that lived inside the state borders. The document contained seven articles and was called "the Declaration on the Protection of National Minorities in Albania". It was signed by the Albanian delegate, Monsignor Fan Noli ${ }^{1}$ and later ratified by the Albanian Parliament on 02 September 1921. ${ }^{2}$ The importance of this international deed stands in the fact that for the first time, the Albanian state, not only formally recognized the national minorities, but it would engage in respecting and guaranteeing their rights. The declaration made it clear that Albanian citizens belonging to minorities of race, religion or language must have the same

1 MFA, File 102, page 30, correspendence of Ministry of Education, Tirana, 1922.

2 MFA, File 102, page 141, Minorities in Albania, League of Nations, Geneva, 1922. 
rights and guarantees as the Albanian nationals. Such minorities were also recognized the right to hold, manage, and control their own income, charity, religious and social schools by freely using their own language and practicing their religion. The Albanian government, in view of such commitments made to the League of Nations, should, within six months from the day of such Declaration, submitted to the Council of the League of Nations full details on the legal status of the religious communities, including churches, monasteries, schools, charity associations of race, religion and language minorities. ${ }^{1}$ However, the Albanian government failed to fulfil such commitments resulting in future disagreements with Greece as regards the number of Greek minorities in Albania.

\subsection{The role of Greek minorities in Albania after 1921}

Following the recognition of national minorities, the Albanian government started the registration of such part of the population. Referring to the data collected by the International Investigating Commission, sent in 1921 by the League of Nations for defining the borderline between Greece and Albania, in the southern part of the country there were 35.000 residents of Greek nationality. Such figure was inconsistent with the inaccurate data provided by the Albanian government on the report submitted to the League of Nations. The report stated that only 16.000 residents of Greek nationality lived in the southern territories of Albania. Independently of the statistic data, the fact was that the Greek minorities made a powerful minority. This type of national minority is established when the same population is divided from the mother trunk by official state borders, or when the population of a certain country migrates over the years and settles inside the official state borders of another country. The settlement usually occurs along the borderline of the mother country. ${ }^{2}$ Having such a substantial importance, the Greek minority claimed that Albania followed the commitments made to the League of Nations. Their claims, strongly supported by the Greek government, consisted in the fact that the Albanian government should not deny their national identity. They claimed that Greek schools in south Albania should still be functioning in preserving Greek language. Greek schools and culture had played an important role in developing the south regions of Albania, given that the Albanian state had been engaged in fighting for its survival by leaving aside the development of Albanian schools. The importance of such schools was becoming increasingly high considering the vast illiteracy of the Albanian society of the time. In the Prefecture of Gjirokaster, there were 39 schools of Greek minorities and the number of pupils attending such schools amounted to $2.614 .^{3}$

The presence of such schools in south regions showed also the tolerance of the Albanian population at a time when nationalism had reached its peak in the Balkans. Other Balkan countries not only did not allow the settlement of national minorities' schools, but they put so much effort on denying the existence of such minorities. With regard to Albania, the government did not hesitate to register such minorities and guarantee their right to vote. Therefore, referring to the number of population, calculated on March 1921 on the occasion of the general elections, there were 33.313 people who spoke Greek $^{4}$ in the Prefecture of Gjirokaster. If we consider the total number of minority population residing in the prefectures of Korce, Gjirokaster and Himara, it made the $17 \%$ of the overall population.

Although the Albanian government had guaranteed the teaching of Greek language and the preservation of cultural heritage, the Greek minorities wanted a place in the local public administration of the areas where they lived. It meant that local representative should not be appointed but they should be elected directly by the voting population. However, such claim opposed to the effective law of the time, which contained no such provision. According to the law of civil procedure, section 7, employees were appointed by the ministries from which they depended, who, in turn were due to first consult the Prefectures. On the other hand, the Ministry of Interior Affairs appointed only its related employees. ${ }^{5}$ The proposal for the

1 Beqir Meta, Minoritetet dhe ndertimi Kombetar ne Shqiperi (1912 - 1924), f.564, Center of albanological Studies, Institute of History, Tirana 2013.

2 Arqile Berxholi, Minorities in Albania (a demographic study), p.23, Tirana, 2005.

3 MFA, file 102, page 131, Tirana, 1922.

4 MFA, file 221, page 9, League of Nations, 1923.

5 Kristo P. Luarasi, Law of civil administration in Albania, Editor "Mbrothesija", Tirana, 1922. 
direct election of public employees was very innovatory for the time; nevertheless, the Albanian government did not allow for its application.

The rights of national minorities, especially with regard to education, would suffer a significant restriction following the proclamation of Albania as heritable parliamentary Kingdom. The new government took a number of reforms aimed at concentrating the power on the central government. The empowerment of central government to the damage of the local government significantly restricted the rights of national minorities. It was clearly reflected on the Fundamental Charter of the Albanian Kingdom. Referring to section 207, the Charter provided that: in conformity with law and within the principles and programs adopted by the government with regard to private schools and their constant supervision by the government, Albanian citizens only could settle private schools.

Foreign citizens, in conformity with law, were only allowed to settle technical and agricultural school with theoretical-practical curricula.

Albanian religious communities could also settle religious school upon permission of the competent ministry and in conformity with law; the number of religious schools for every community, as well as the number of students was determined by the competent ministry by decree of the Council of Ministers. ${ }^{1}$

This section was in contradiction with the Declaration on minorities, especially with section 5 , already signed by Albania as a precondition for its adherence to the League of Nations. Paragraph one of section 207 provided that only Albanian citizens were given the opportunity to settle various private schools, whereas section 5 , acknowledged to Albanian citizens, who were part of racial, religious or language minorities, the right to hold, manage and supervise their income, or establish in the future charity, religious or social schools, or other educational buildings, being also entitled to freely use their language and have their own religion. Section 207, paragraph two, restricted the right of foreigners to settle schools. It pointed out that foreigners were only allowed to settle technical or agricultural schools with theoretical-practical curricula. Furthermore, paragraph three provided that religious communities had restricted rights with regard to settlement and management of schools. Government, through the relevant ministry, was entitled to determine not only the number of schools necessary to the religious communities, but even the number of pupils who should attend such schools. Such measures taken by the Albanian government were strongly contested not only by such national minorities, but even by Greece to the Council of League of Nations. Many times, the Helenian government would remind the Albanian government its commitments to the international arena. Independently of the adoption of laws that restricted the rights of national minorities, Albania, still remained one of the most tolerant government in the Balkans. This is clearly indicated by the fact that minority schools remained opened under the settlement of the communist regime in Albania.

\subsection{National minorities in Albania during the settlement of the Dictatorship}

With the end of the Second World War, for almost 50 years Albania remained under the communist regime, isolated from the rest of the world. The one-party system leaded by the dictator Enver Hoxha would approve a number of laws aimed at denying the citizens' rights. Such laws would deny even the rights of national minorities, which had been previously recognized with the adherence of Albania to the League of Nations. As far as individual rights were concerned, the situation would aggravate with the adoption of the constitution of year 1976. The communist regime intended to settle a totalitarian state based on a homogenous society. Such homogeneity could be achieved by suppressing any kind of diversity, including ethnic diversity. Although from the legal viewpoint there was a gap in the recognition of national minorities' rights, the state provided statistic data on ethnic minorities in Albania to the national civil registry. In this respect, we find of great help the general registry of population and building of 1989 published by the Agency of Statistics. The following tables give the number of minority population compared to the overall number of population and their distribution by districts.

1 Aleks Luarasi, Juridical acts on history of law and state in Albania, p.132, "Luarasi", Tirana, 1999. 
The number of minority population compared to the overall population of the country:

\begin{tabular}{lll}
\hline Year & No. of minority population & $\begin{array}{l}\text { Percentage compared to the } \\
\text { overall population }\end{array}$ \\
1960 & 44.570 & $2,7 \%$ \\
1979 & 54.687 & $2,1 \%$ \\
1989 & 64.816 & $2,0 \%$ \\
\hline
\end{tabular}

Table no.1

Number of national minorities divided by districts in 1989:

\begin{tabular}{llllll}
\hline Total & Gjirokaster & Sarande & Korce & Tirana & Other districts \\
64.816 & 20.395 & 36.773 & 4.706 & 852 & 2.090 \\
\hline
\end{tabular}

Table no. $2^{1}$

Number of Greek minorities divided by districts in 1989

\begin{tabular}{|c|c|c|c|c|}
\hline Total & Gjirokaster & $\begin{array}{l}\text { Saranda and } \\
\text { Delvina }\end{array}$ & Tirana & Other districts \\
\hline 58.758 & 19.921 & 36.531 & 610 & 1.696 \\
\hline
\end{tabular}

Table no.3

The data contained in the above tables show two important aspects. The first relates to the fact that, as stated by all governments following the end of the Second World War, Albania has a homogenous population, where minorities make more or less the $2 \%$ of the overall population. The second aspect emphasizes the fact that Greek minorities are the most important community of national minorities in Albania. The number of national minorities in 1989 amounted to 64.816 residents, of which, the number of Greek minority amounted to 58.758 residents. The fact that such minority is concentrated in south Albania, in the districts of Gjirokaster, Saranda and Delvina, demonstrates its strong national identity, independently of the restrictions imposed by the communist regime.

\subsection{Respect for minorities after the fall of the communist regime}

The fall of the communist regime in Albania and the judicial reforms that followed made it possible for a significant improvement of the national minorities' rights in the country. The lack of a new post-communist constitution was temporarily filled by the Main Constitutional Provisions. Such provisions included even some international norms related to human rights. Accordingly, section 4 of the Main Provision clearly provided: The Republic of Albania recognizes and guarantees the fundamental human rights and freedoms to ethnic individuals and minorities in compliance with the international documents. In 1993, the Albanian Parliament adopted law no. 7692 "Fundamental Human Rights and Freedoms". According to section 25 of that law, "nobody should be discriminated because of their gender, race, ethnicity, language, religion, economical, financial, educational, and social status, political and parental affiliation, and any other personal circumstance". ${ }^{2}$ Section 26 related to minorities' rights provided that: "individuals belonging to national minorities have the right to exercise, without any form of discrimination and being equal before the law, any fundamental human right and freedom. They have the right to express, preserve and develop freely their ethnic, cultural, religious, and linguistic identity, to teach and learn their mother language, as well as to adhere to organizations and associations aimed at protecting their identity and interest.

On 28 November 1998, the new Constitution became effective upon proclamation by decree of the President of the Republic of Albania. The new Constitution had a relevant importance in terms of national minorities' rights, whereby such rights were guaranteed in the constitutional law of the state. In this respect, the second part of the Constitution 
related to human fundamental rights and freedoms, section 18 , affirms that all men are equal before the law. According to such section, the law equally protects all citizens residing inside the territory of the Republic of Albania. Such equality is further affirmed in the second section, wherein it is specifically emphasized that: "nobody can be unjustly discriminated for such reasons as gender, race, religion, ethnicity, language. ${ }^{1}$ Section 18 affirms the right to nondiscrimination, whereas section 20 goes further by guaranteeing to such minorities full rights and freedoms before the law. This section provides that: "individuals belonging to national entities are totally equal before the law in exercising their rights and freedoms. Paragraph 2 provides in detail that: "Minorities have the right to express freely, without being hindered or obliged, their ethnic, cultural, religious, and linguistic affiliation. They have the right to preserve and develop, teach and learn mother language, as well as to adhere to organizations and associations aimed at protecting their identity and interest."

In 29 June 1995, Albania took an important step at the defence of the minorities by signing the Framework Convention of the European Council for the protection of national minorities. It was ratified by the Parliament of the Republic of Albania by law no. 8496 on 03 June 1999 and it was made effective one year later. ${ }^{2}$ The Convention is an important document as it covers a broad range of issues relating not only to the promotion of non-discrimination of national minorities, but also to the commitment of Albania in adopting a series of reforms aimed at efficient equality. Furthermore, the signatory states of such Convention had to promote favouring terms to the preservation and development of culture, religion, language and traditions. Independently of its importance, the Framework Convention contains no definition of the concept "national minorities", as there is no such general definition accepted by all member states of the European Council. ${ }^{3}$ In other words, states are to decide which groups may be included by the Convention inside their territory. It would be better that the Convention provided an accurate definition of the term "national minorities", so as its implementation produced the desired effects for the populations residing inside the territories of the signatory states.

\subsection{Greek minorities in Albania after 1991}

With the fall of the communist system and the establishment of the democracy, the Albanian society underwent significant changes to the affirmation of citizens' rights and freedoms. The opening of borders produced great demographic movements of the population to the neighbouring countries such as Italy and Greece. Certainly, such changes affected even the Greek minority, which had the chance to immigrate to Greek in search of a better life. The great demographic movements provide no clear framework of the overall number of the Greek minorities in Albania; however, some scholars believe that the number of such minorities does not exceed 70 thousand residents. Nevertheless, referring to the statistic data related to nationality provided in the self-declaration, inserted in the civil registry of 2011, Albanians of Greek nationality were 24.242 residents. ${ }^{4}$ Such inaccuracies in the statistic data are due to the immigration of Greek minorities. In all areas where the Greek minority is concentrated, it is believed that over $50 \%$ of the population has immigrated. The reasons of such immigration related to the better working opportunities and living conditions. Greek minorities have been constantly supported by the Greek government with regard to staying permits, employment and education of children. The recent democratic changes in Albania, with regard to legislation, have brought essential improvements to the position of the Greek minorities. Such minorities enjoy full rights in accordance with most liberal European standards and values that regulate the life of an open democratic and pluralist society. Notwithstanding the problems, which the Albanian society has faced during the transition phase, Greek minorities have been guaranteed all rights pursuant to the European and international standards.

\section{Conclusions}

Greek minorities in Albania have played an important role not only to the development of the Albanian society, but also to the consolidation of the Albanian state. Their cultural values have been a significant contribution to the establishment of Albanian national identity. The recognition of Greek minorities by the Albanian government is one of

1 Luan Omari, Aurela Anastasi, Constitutional Law, p. 70, Editor ABC, Tirane, 2010.

2Minorities and protection of their rights in Albania, p. 13, Albanian Center for Human Rights, Tirana, 2003.

3Minorities rights, p.5, www.osce.org

4Ethnic minorities in Albania, http://www.mfa.gov.al/dokumenta/raporti\%20i\%20pare\%20(ang).pdf, 31 January 2013 
the most important events, as it gave Albania the opportunity to be recognized by the League of the Nations as an independent member state with full rights. The adherence of Albania to such international organization, on the other side, was a guarantee to the recognition and respect of national minorities' rights in general and of Greek minorities in particular. They were given the chance to preserve and inherit their values and national identity. With the settlement of the communist regime, we came across a denial of individual rights and freedoms. The denial of such freedoms affected even Greek minorities, which lost even the status of national minority. To regain such status, they had to wait for the fall of the communist system and establishment of democratic pluralism, which aimed at the affirmation of the rule of law. During such period, Albania would adopt a number of laws aimed at guaranteeing equal rights before the law and non-discrimination of national minorities. The economic transition that Albanian democracy is going through have made Greek minority population, as well as Albanian residents, immigrate to the neighbouring countries for a better life. Independently of such difficulties, the Greek minorities enjoy full rights according to European and international standards. Their rights are guaranteed even by the Albanian constitution, which recognizes full rights and freedoms before the law.

\section{Bibliography}

[1] Books

[2] Adrian Papajani, Minorities Rights, p. 91, "Seiko", Elbasan, 2005.

[3] Aleks Luarasi, Juridical acts on history of law and state in Albania, p.132, "Luarasi", Tirana, 1999

[4] Arqile Berxholi, Minorities in Albania (demographic study), p.23, Tirana, 2005

[5] Beqir Meta, Minorities and national consturciton in Albania (1912 - 1924), p.564, Center of Albanologic Studies, Institute of History, Tirana 2013

[6] Kristo P. Luarasi, Civil administration law of the Albanian State, Editor "Mbrothesija", Tirana, 1922

[7] Luan Omari, Aurela Anastasi, Constitutional Law, f. 70, Editor ABC, Tirana, 2010

[8] Minorities and protection of their rights in Albania, f. 13, Albanian Center for the Human Rights, Tirana, 2003.

[9] Official documents

[10] MFA, File 102, page 30, Correspondence of Ministry of Education, Tirana, 1922

[11] MFA, file 102, page 131, Tirana, 1922

[12] MFA, file 102, page 141, Minorities in Albania, League of Nations, Geneva, 1922

[13] MFA, file 221, page 9, League of Nations, 1923

[14] Website

[15] Minorities rights, p.5, www.osce.org

[16] Ethnic minorities in Albania, http://www.mfa.gov.al/dokumenta/raporti\%20i\%20pare\%20(ang).pdf, 31 January 2013. 